\title{
Dissolved free amino acids, combined amino acids, and DNA as sources of carbon and nitrogen to marine bacteria
}

\author{
Niels O. G. Jørgensen ${ }^{1}$, Niels Kroer ${ }^{2, *}$, Richard B. Coffin ${ }^{3}$, Xiao-Hua Yang ${ }^{4}$, \\ Cindy Lee ${ }^{4}$
${ }^{1}$ Microbiology Section, Department of Ecology and Molecular Biology, Royal Veterinary and Agricultural University, Rolighedsvej 21, DK-1958 Frederiksberg C, Denmark
${ }^{2}$ Department of Marine Ecology and Microbiology, National Environmental Research Institute, Frederiksborgvej 399, DK-4000 Roskilde, Denmark
${ }^{3}$ United States Environmental Protection Agency, Gulf Breeze Environmental Research Laboratory, Sabine Island, Florida 32561, USA \\ ${ }^{4}$ Marine Sciences Research Center, State University of New York, Stony Brook, New York 11794-5000, USA
}

\begin{abstract}
Utilization of naturally-occurring dissolved free and combined amino acids (DFAA and DCAA) and dissolved DNA (D-DNA) was studied in batch cultures of bacteria from 2 shallow marine environments, Santa Rosa Sound (SRS), Florida, USA, and Flax Pond (FP), Long Island, New York, USA. In addition to control experiments, cultures were enriched with various sources of $C$ and $N$. In the SRS cultures, net $C$ assimilation of DCAA, DFAA and D-DNA made up from 42 to $60 \%$ of net bacterial $C$ production. The average, relative incorporation of $C$ from DCAA, DFAA and D-DNA was $0.13,0.77$ and 0.10 , respectively. The corresponding values of $\mathrm{N}$ were $0.10,0.81$ and 0.09 . Addition of $\mathrm{NH}_{4}{ }^{+}$, DFAA, or both, increased the incorporation of DCAA, DFAA and D-DNA. Incorporation of $N$ from DCAA, DFAA and D-DNA equaled 111 to $219 \%$ of the bacterial N production. Including incorporation of $\mathrm{NH}_{4}{ }^{+}$and release of $\mathrm{NO}_{3}{ }^{-}$, calculated net bacterial $\mathrm{N}$ incorporation made up 48 and $290 \%$ of bacterial $\mathrm{N}$ production. In the FP experiment, net assimilation of DCAA, DFAA and D-DNA equaled 66 to $91 \%$ (average $77 \%$ ) of net bacterial C production. Largely all C incorporation was due to assimilation of DFAA. Enrichment of the cultures with $\mathrm{NH}_{4}{ }^{+}$, glucose, methylamines, and high-molecular-weight dissolved organic matter all increased bacterial production. Net $N$ incorporation of DCAA, DFAA and D-DNA corresponded to between 100 and $180 \%$ of net bacterial $\mathrm{N}$ production. In 3 cultures DFAA were the dominant $(>50 \%)$ bacterial $\mathrm{N}$ source. In the other cultures, DFAA and $\mathrm{NH}_{4}{ }^{+}$were similar in importance as an $\mathrm{N}$ source, and together they accounted for 80 to $99 \%$ of bacterial $\mathrm{N}$ incorporation. Including uptake of $\mathrm{NH}_{4}{ }^{+}$and uptake or release of $\mathrm{NO}_{3}{ }^{-}$in the $\mathrm{N}$ budgets, bacterial $\mathrm{N}$ incorporation equaled 155 to $413 \%$ of bacterial $N$ production. The reason for this apparently excessive $N$ uptake in both sets of cultures may be the release of organic nitrogen compounds
\end{abstract}

\section{INTRODUCTION}

In aquatic ecosystems, activity of heterotrophic bacteria is a key process in the cycling of nitrogen. Duning bacterial metabolism, elements of organic matter are remineralized or used by the bacteria in their biosynthesis. Recent studies suggest that dissolved free amino acids (DFAA) and $\mathrm{NH}_{4}{ }^{+}$may be the major

\footnotetext{
-Addressee for reprint orders
}

sources of $\mathrm{N}$ to aquatic bacteria. In marine bacteria, DFAA and $\mathrm{NH}_{4}{ }^{+}$have been found to sustain from 8 to about $50 \%$, and from 22 to $88 \%$, respectively, of the bacterial N demand (Tupas \& Koike 1990, Goldman \& Dennett 1991, Keil \& Kirchman 1991a, Simon 1991). Keil \& Kirchman (1991a) observed that DFAA and $\mathrm{NH}_{4}{ }^{+}$were often equally important, sustaining $90 \%$ or more of the bacterial $\mathrm{N}$ requirement. Whether $\mathrm{NH}_{4}{ }^{+}$or DFAA is the dominant $\mathrm{N}$ source appears to depend upon the composition of the available dissolved organic compounds (Goldman \& Dennett 1991) 
Organic nitrogen compounds other than DFAA may also be quantitatively important to bacteria. Among such compounds, most attention has been paid to dissolved combined amino acids (DCAA, i.e peptides and proteins) and dissolved DNA (D-DNA). Aquatic bacteria have been shown to possess a high capacity for assimilation of DCAA (Hollibaugh \& Azam 1983, Coffin 1989). Tupas \& Koike (1990) measured bacterial consumption of dissolved organic $N$ (DON) and found that most of the consumed DON was DFAA and DCAA corresponding to 12 to $50 \%$ of the bacterial $\mathrm{N}$ production. Bacterial uptake of D-DNA has been measured in both lacustrine and marine waters, with turnover times of added DNA tracer of less than 10 h (Paul et al. 1987 1989), but the quantitative significance of DNA uptake to bacterial $\mathrm{N}$ demand has not been determined.

In addition to being a source of nitrogen, DFAA, DCAA and D-DNA are potential contributors of carbon to heterotrophic bacteria. DFAA are reported to sustain up to about $40 \%$ of the bacterial C production in fresh and sea water (Jørgensen 1987, 1990, Fuhrman 1990, Simon 1991). The quantitative importance of $C$ from DCAA and D-DNA to bacterial production has not yet been determined.

The purpose of our study was to determine the importance of DFAA, DCAA and D-DNA as sources of $N$ and $C$ to marine bacteria grown in batch cultures. Since the assimilation of DFAA, DCAA and D-DNA may be expected to depend on the availability of other organic and inorganic compounds, some bacterial cultures were enriched with various naturally occurring substances

\section{MATERIALS AND METHODS}

Experimental design. Seawater for bacterial batch cultures was collected in 2 shallow, coastal habitats, Santa Rosa Sound (SRS), Northwestern Florida, USA, and Flax Pond (FP), a marine embayment of Long Island Sound, New York, USA. Water temperatures and salinities at the sampling time were $25^{\circ} \mathrm{C}$ and 25 ppt (SRS) and $23^{\circ} \mathrm{C}$ and $27 \mathrm{ppt}$ (FP). The cultures consisted of $50 \%$ (SRS) or $5 \%$ (FP) $1.0 \mu \mathrm{m}$ filtered seawater diluted with $50 \%$ and $95 \% 0.2 \mu \mathrm{m}$ filtered seawater, respectively. Filter cartridges of 0.2 and $1.0 \mu \mathrm{m}$ pore size and a peristaltic pump (all from Millipore, USA) were used for the filtrations. After filtration and mixing, the batch cultures were transferred to duplicate $10 \mathrm{l}$ carboys, which were incubated at laboratory temperature (approximately $25^{\circ} \mathrm{C}$ ) in the dark to reduce the risk of phototrophic growth. Samples were taken at regular intervals to measure various growth parameters as described below. The carboys were shaken before each sampling. A possible release of dissolved organic matter from the Millipore cartridges during filtration was tested by comparing the concentration of DFAA in cartridge-filtered, Millipore HA membrane-filtered and polycarbonate membranefiltered (Nuclepore Corp., USA) seawater. Concentrations of DFAA in the 3 filtrates were similar within a $5 \%$ confidence limit (data not shown). Although possible changes of concentrations of DCAA and D-DNA were not measured, the DFAA measurements suggest that the filtration did not alter the ambient pools of dissolved organic nutrients.

Several carboys were enriched with various inorganic and organic compounds. In the SRS experiment,

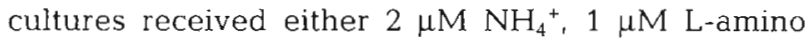
acids (equimolar mixture of ala, arg, asp, glu, gly, his, ile, leu, lys, phe, pro, ser, thr, tyr, val), or a mixture of both. In the FP experiment, batch cultures were amended with $1 \mu \mathrm{M} \mathrm{NH}_{4}{ }^{+}, 1 \mu \mathrm{M}$ glucose, a combination of $0.6 \mu \mathrm{M}$ mono-, di-and trimethylamines, or a $3 \times$ enrichment of high-molecular-weight (>5000 Daltons) dissolved organic matter (HMW-DOM), concentrated from FP water. In several cases, a mixture of some of these compounds was added. HMW-DOM was prepared by filtering FP water through an Amicon Diaflo YM5 ultrafiltration membrane in an Amicon Intermediate Volume TCF10 Thin Channel Ultrafiltration system (Amicon, USA).

Microbiological and chemical analyses. At regular intervals, subsamples for analysis of various growth parameters were taken. The analyses included:

Dissolved free amino acids (DFAA): Assimilation of DFAA was measured by adding a mixture of ${ }^{14} \mathrm{C}$ labeled L-amino acids (same as mentioned above, but with a molar composition similar to algal proteins; specific activity $>50 \mathrm{mCi}\left(\mathrm{mg}\right.$-at. C) ${ }^{-1}$; ICN Biochemicals, USA). To triplicate $20 \mathrm{ml}$ water samples (one was a control with $2 \%$ formaldehyde) were added about 0.01 $\mu \mathrm{Ci}{ }^{14} \mathrm{C}$ amino acid mixture, corresponding to $3.6 \mathrm{nmol}$ DFAA $1^{-1}$. The samples were incubated until a maximum uptake of $20 \%$ of the radioisotopes was reached, after which the samples were killed with formaldehyde ( $2 \%$ final concentration). The incubation periods ranged between about $15 \mathrm{~min}$ (at $24 \mathrm{~h}$ (SRS) and $26 \mathrm{~h}$ (FP) incubation] and 60 to $80 \mathrm{~min}$ at start of the experiments. The samples were filtered through $0.2 \mu \mathrm{m}$ membrane filters (Millipore HA), which were radioassayed by liquid scintillation counting (LSC). Respiration of the assimilated DFAA was not determined. Concentrations of DFAA were determined in $0.2 \mu \mathrm{m}$ Millipore HA filtered water samples. Individual DFAA were measured as fluorescent OPA-derivatives by high pressure liquid chromatography (HPLC) according to Lindroth \& Mopper (1979). The HPLC equipment consisted of the following Millipore/Waters (USA) apparatuses: a Maxima 820 data acquisition 
module, two 510 Waters pumps, a Waters 712 WISP autoinjector with facilities for automatic OPA derivatization, and a Waters Nova-Pak $\mathrm{C}_{18} 4 \mu \mathrm{m}$ particle size column $(3.9 \times 150 \mathrm{~mm})$. For detection, an Applied Biosystems (USA) model 980 fluorescence detector was used. The chromatographic solvents were (A) 35:65 v/v water:methanol and (B) $5.3 \mathrm{mM} \mathrm{Na}_{2} \mathrm{HPO}_{4}, 4.8 \mathrm{mM}$ sodium acetate, $2 \%$ methanol and $2 \%$ tetrahydrofuran in water The pumping rate was $1.0 \mathrm{ml} \mathrm{min}{ }^{-1}$. The following solvent gradient was used for the amino acid analysis: 0 min $(24 \% \mathrm{~A}, 76 \% \mathrm{~B}) \rightarrow 27 \mathrm{~min}(100 \% \mathrm{~A}$, $0 \% \mathrm{~B}) \rightarrow 30 \mathrm{~min}(100 \% \mathrm{~A}, 0 \% \mathrm{~B}) \rightarrow 32 \mathrm{~min}(24 \% \mathrm{~A}$, $76 \%$ B). For equilibration of the column an injection interval of 45 min was applied. An amino acid standard mixture (AA-S-18, Sigma Chemical Co., USA) received additions of asparagine, glutamine, $\gamma$-aminobutyric acid, and ornithine and was used for calibration of the analysis. The amino acid mixture was diluted to $250 \mathrm{nM}$ of each amino acid before injection. No internal standards were added to the analyzed samples. Analytical precision was about $5 \%$.

Dissolved combined amino acids (DCAA): Changes in concentrations of DCAA were followed to measure net bacterial utilization or release of DCAA. Water samples, similar to those used for DFAA analysis, were acidified with $30 \%$ Suprapur $\mathrm{HCl}$ (Merck, Germany) to a final concentration of $6 \mathrm{M} \mathrm{HCl}$, and were hydrolyzed for 24 h at $115^{\circ} \mathrm{C}$ in $\mathrm{N}_{2}$-filled glass ampules. The hydrolyzates were evaporated at $105^{\circ} \mathrm{C}$, redissolved in Milli-Q water (Millipore) and quantified with the above-mentioned HPLC procedure. Blanks were prepared both by hydrolysis of Milli-Q water and by evaporation of undiluted Suprapur $\mathrm{HCl}$ at $105^{\circ} \mathrm{C}$. After hydrolysis and evaporation the samples were redissolved in Milli-Q water and analyzed for DFAA. The concentration of DFAA in both types of blanks always were $<95 \mathrm{nM}$. The DCAA samples were corrected for this concentration.

Dissolved DNA (D-DNA): Bacterial utilization of DDNA was determined by following ambient DNA concentrations and assimilation rates of [ ${ }^{3} \mathrm{H} \mid$-labelled DNA. Escherichia coli DNA was digested with Eco R1 and labelled with $\left[{ }^{3} \mathrm{H}\right]$-deoxy-ATP by nick translation according to instructions provided by the manufacturer (Bethesda Research Laboratory, USA). The labelled DNA fragments were purified on a Sephadex 50 column (Maniatis et al. 1982). Specific activity of the DNA was $1.26 \mu \mathrm{Ci} \mu \mathrm{g}^{-1}$. $\left[{ }^{3} \mathrm{H}\right] \mathrm{DNA}$ was added to $10 \mathrm{ml}$ water samples to a concentration of $1.6 \mu \mathrm{g} \mathrm{l}^{-1}$. After a $4 \mathrm{~h}$ incubation, the water samples were filtered through $0.2 \mu \mathrm{m}$ Millipore HA filters and radioassayed. Formaldehyde-killed samples were treated with similar amounts of $\left[{ }^{3} \mathrm{H}\right] \mathrm{DNA}$ for use as blanks, but radioactivity on the filters was unrealistically high. This may be due to structural alterations of DNA and adsorption to the membrane filters. Instead, the 5 lowest $\left[{ }^{3} \mathrm{H}\right] \mathrm{DNA}$ uptake rates encountered during the experiment were used as blanks, thus making the uptake rates reported here minimal values. Respiration of the assimilated DNA was not measured. Natural concentrations of DNA were measured according to procedure by Karl \& Bailiff (1989). A DNA standard curve was prepared from a solution of calf thymus DNA (Sigma Chemical Co.).

Bacterial production and abundance: In the SRS batch cultures, bacterial production was measured by leucine incorporation into bacterial proteins according to Kirchman et al. (1985) with modifications by Jørgensen (1992a). To triplicate $5 \mathrm{ml}$ water samples (one a formaldehyde-killed control) was added $100 \mathrm{nM}$ leu-

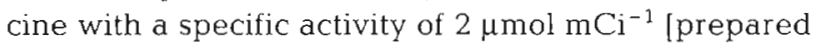
from unlabelled and ${ }^{3} \mathrm{H}$ leucine (specific activity of $64 \mathrm{Ci} \mathrm{mmol}^{-1}$; New England Nuclear, USA)]. The samples were incubated for 30 to $60 \mathrm{~min}$, followed by addition of $5 \mathrm{ml} 10 \%$ trichloroacetic acid (TCA). After 60 min, the TCA precipitates were filtered onto $0.2 \mu \mathrm{m}$ membrane filters and radioassayed.

In the FP samples, the thymidine incorporation procedure by Fuhrman \& Azam (1980) was used for measurements of bacterial production. $\left[{ }^{3} \mathrm{H}\right]$ thymidine $(65 \mathrm{Ci}$ mol $^{-1}$; Dupont, NEN Research Products) was added to cold thymidine to a specific activity of $2.22 \mu \mathrm{Ci} \mathrm{mmol}^{-1}$. Triplicate $5 \mathrm{ml}$ samples (one a formaldehyde-killed control) were incubated with $10 \mathrm{nM}$ thymidine for 30 to $60 \mathrm{~min}$. The incubations were stopped by addition of $5 \mathrm{ml} 10 \%$ cold TCA. After $30 \mathrm{~min}$, the TCA precipitates were filtered onto $0.2 \mu \mathrm{m}$ membrane filters and radioassayed.

Bacterial abundance was measured by acridine orange direct counts (Hobbie et al. 1977).

Particulate organic carbon (POC): For POC analysis, $75 \mathrm{ml}$ water samples were filtered through pre-ashed $\left(500^{\circ} \mathrm{C}, 24 \mathrm{~h}\right) 25 \mathrm{~mm}$ Whatman GF/F filters. The filters were dried and stored in a heated vacuum desiccator at $45^{\circ} \mathrm{C}$ until assayed on a Carlo Erba CHN Analyzer NA 1500. Correction for carbon on blank filters (no water filtered) was applied to the POC values. In similar studies, 93 to $99 \%$ of bacteria in an early stationary phase were found to be retained on GF/F filters (Kroer 1993).

Dissolved organic carbon (DOC): Samples for DOC determination were taken from the Whatman GF/F filtrates. Samples of $5 \mathrm{ml}$ were stored in sealed precombusted glass ampules at $-18^{\circ} \mathrm{C}$ until analysis. Inorganic carbon was purged from the thawed samples by bubbling with $\mathrm{N}_{2}$ gas for 6 min after acidification with concentrated $\mathrm{HCl}$ to $\mathrm{ca} \mathrm{pH} 1$. Concentrations of DOC were measured using a Shimadzu TOC 5000 Analyzer (oxidation at $680^{\circ} \mathrm{C}$, Pt-covered aluminum oxide as a catalyst) 
Methylamines: Mono-, di-, and trimethylamine were measured in $0.2 \mu \mathrm{m}$ Millipore filtered water samples. The amines were concentrated by a circulation diffusion method and analyzed by gas chromatography (Yang et al. 1993).

Ammonium, nitrite and nitrate were measured using Technicon Auto Analyzer standard procedures (Technicon, USA).

Carbon and nitrogen budgets. Bacterial carbon and nitrogen budgets were calculated from net assimilation rates of DFAA and D-DNA uptake. Carbon and nitrogen content of DCAA and DFAA was based upon the carbon and nitrogen content of the individual amino acids. For D-DNA, carbon and nitrogen contents of 33 and $16 \%$, respectively, were used.

\section{RESULTS}

\section{Santa Rosa Sound}

Abundance and production of bacteria. The batch cultures were sampled over $74 \mathrm{~h}$, but since the bacterial populations reached maximum abundance after 24 to $36 \mathrm{~h}$, only results of the first $48 \mathrm{~h}$ are presented (Fig. 1). During the initial $24 \mathrm{~h}$, the abundance of bacteria increased from $1.0 \times 10^{6}$ cells $\mathrm{ml}^{-1}$ to between 1.8 and $2.0 \times 10^{6} \mathrm{cells} \mathrm{ml}^{-1}$ in all cultures (Fig. 1A). During the rest of the period, minor variations of the number of bacteria occurred. Incorporation of leucine in the control and the $\mathrm{NH}_{4}{ }^{+}$-enriched cultures oscillated during the experiment with peaks at 12 and $36 \mathrm{~h}$ (Fig. 1B). In the DFAA-enriched and the $\mathrm{NH}_{4}{ }^{+} /$DFAA-enriched cultures, incorporation of leucine increased gradually during most of the incubation period (Fig. 1B). The relatively low leucine incorporation of the DFAAenriched cultures likely reflects competition from other amino acids added, rather than a decrease of the protein synthesis.

Dissolved combined amino acids (DCAA). During the first $24 \mathrm{~h}$, concentrations of DCAA were reduced in all cultures (Fig. 1C). The largest decline occurred in the $\mathrm{NH}_{4}{ }^{+} /$DFAA-enriched cultures. In the DFAAenriched cultures, the decrease in DCAA continued for $48 \mathrm{~h}$. In the other cultures concentrations of DCAA were more variable after $24 \mathrm{~h}$.

Dissolved free amino acids (DFAA). In the control and the $\mathrm{NH}_{4}{ }^{+}$-enriched cultures, the initial DFA. concentration of $190 \mathrm{nM}$ was reduced to between 50 and $70 \mathrm{nM}$ during the first $24 \mathrm{~h}$ (Fig. 2A). In the DFAAenriched cultures, the concentration was reduced from $1190 \mathrm{nM}$ at start, to $125 \mathrm{nM}$ (DFAA-enriched) and $70 \mathrm{nM}\left(\mathrm{NH}_{4}{ }^{+} / \mathrm{DFAA}\right.$-enriched $)$ at $24 \mathrm{~h}$. Later in the experiment, the DFAA concentrations increased in all cultures. During the initial $24 \mathrm{~h}$, the assimilation of
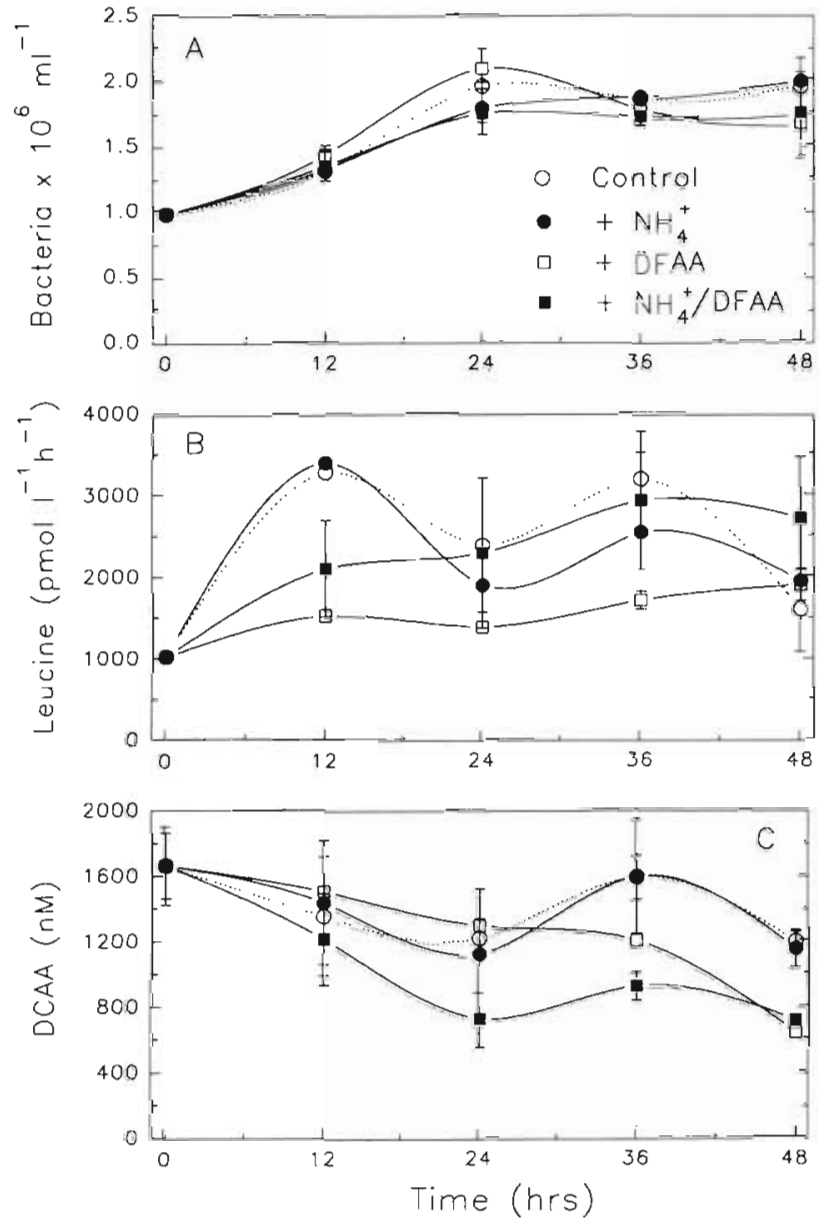

Fig. 1. Santa Rosa Sound. (A) Bacterial abundance, (B) incorporation of leucine and (C) concentrations of dissolved combined amino acids (DCAA) in the batch cultures. Means \pm 1 $\mathrm{SD}(\mathrm{n}=4 ; 2$ from each batch) are shown. Additions: $2 \mu \mathrm{M}$ $\mathrm{NH}_{4}{ }^{+}$and/or $1 \mu \mathrm{M}$ DFAA

DFAA increased in the cultures (Fig. 2B). Addition of DFAA caused only a slightly a higher assimilation rate. This may be due to an initial high respiration rate, as discussed later. At $48 \mathrm{~h}$, the assimilation had decreased, except in the control cultures.

Dissolved DNA (D-DNA). The concentration of D-DNA was initially $3.7 \mu \mathrm{g} \mathrm{l}^{-1}$ and varied only a little (3 to $5 \mu \mathrm{g} \mathrm{l}^{-1}$ ) during the rest of the experiment (Fig. 2C). Assimilation of DNA increased slightly from 1 to between 1.5 and $2.0 \mu \mathrm{g} \mathrm{l}^{-1} \mathrm{~h}^{-1}$ (control and $\mathrm{NH}_{4}{ }^{+} /$DFAA-enriched cultures), or decreased to between 0.3 and $0.7 \mu \mathrm{g} \mathrm{l}^{-1} \mathrm{~h}^{-1}\left(\mathrm{NH}_{4}{ }^{+}\right.$and DFAAenriched cultures) at $48 \mathrm{~h}$ (Fig. 2D).

Inorganic nitrogen. Except for the $\mathrm{NH}_{4}{ }^{+}$-enriched cultures, ammonium and nitrate concentrations were below the detection limit, i.e. $<0.1 \mu \mathrm{M}$ (data not shown). In the $\mathrm{NH}_{4}{ }^{+}$-enriched cultures, $\mathrm{NH}_{4}{ }^{+}$was reduced from $2.00 \mu \mathrm{M}$ initially, to $0.72,0.91$ and $0.70 \mu \mathrm{M}$ at 24,36 and $48 \mathrm{~h}$, respectively. $\mathrm{NO}_{3}{ }^{-}$increased from 


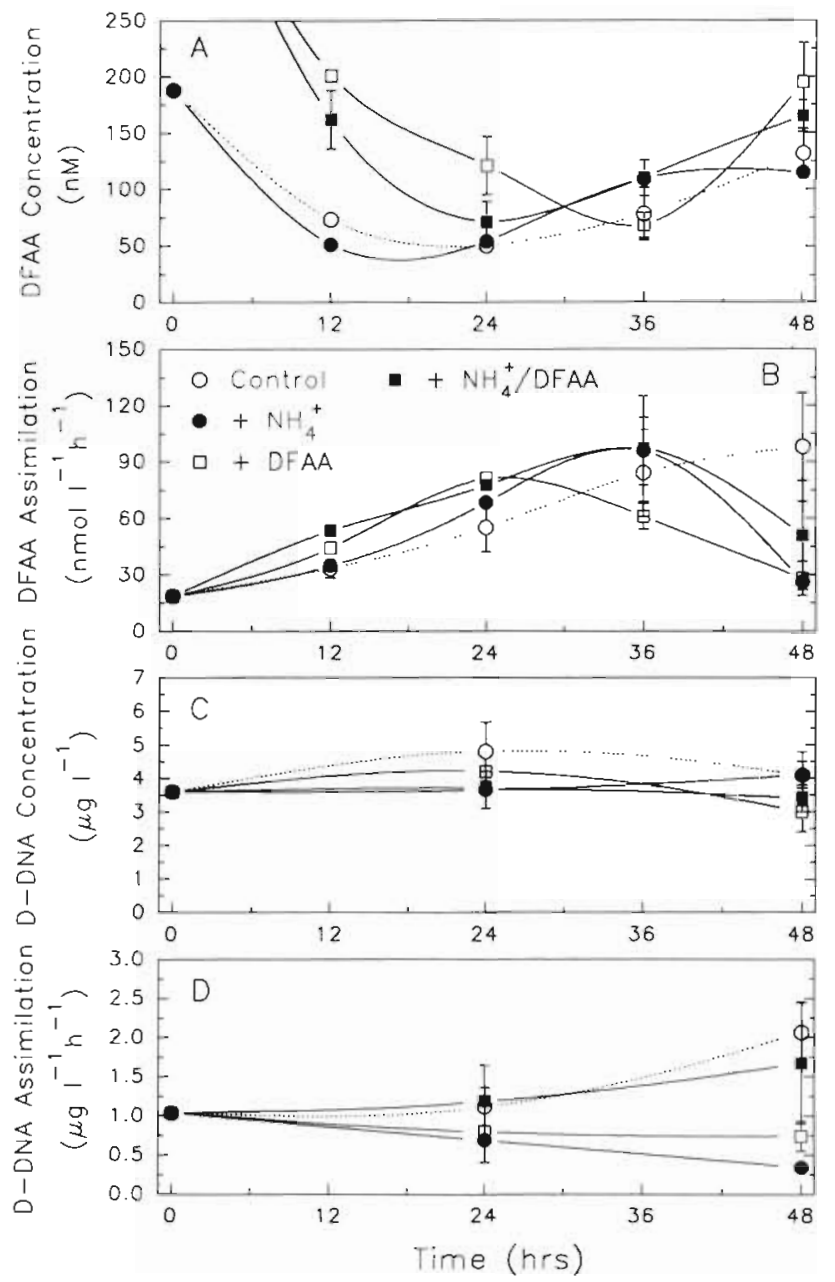

Fig. 2. Concentrations and net assimilation rates of ( $A$ and $B$ ) dissolved free amino acids (DFAA) and (C and D) dissolved DNA (D-DNA) in the batch cultures. In (A), the initial concentration of DFAA in the DFAA-enriched samples was $1190 \mathrm{nM}$

Means $\pm 1 \mathrm{SD}$ ( $\mathrm{n}=4 ; 2$ from each batch) are shown

non-detectable, to $0.89,2.28$ and $2.44 \mu \mathrm{M}$ at 24,36 and $48 \mathrm{~h}$, respectively. In the $\mathrm{NH}_{4}^{+} /$DFAA-enriched cultures, $\mathrm{NH}_{4}{ }^{+}$decreased from $2.00 \mu \mathrm{M}$, to $1.75,1.20$ and $1.28 \mu \mathrm{M}$, while $\mathrm{NO}_{3}{ }^{-}$increased to 1.71 and $3.17 \mu \mathrm{M}$, but decreased to $1.68 \mu \mathrm{M}$ at 24,36 and $48 \mathrm{~h}$, respectively.

Carbon budget. Bacterial carbon and nitrogen budgets were calculated for the initial $24 \mathrm{~h}$ of incubation when there was an actively growing bacterial population in all cultures. Consumption of dissolved organic carbon (DOC) ranged from $6.88\left(\mathrm{NH}_{4}{ }^{+}\right.$-enriched cultures) to $11.46 \mu \mathrm{g} \mathrm{Cl}^{-1} \mathrm{~h}^{-1}$ (DFAA-enriched cultures) (Table 1). Bacterial production determined on basis of cell volumes was statistically similar in three of the cultures, but a higher production was calculated for the DFAA-enriched cultures. When related to DOC consumption, the bacterial carbon growth efficiency varied from 31.0 to $46.4 \%$. Except for the DFAA-enriched cultures, the bacterial production determined from leucine incorporation agreed with the cell volumebased production (Table 1). In the DFAA-enriched cultures, incorporation of leucine suggested a $50 \%$ lower production then did the size of the bacteria. This was probably caused by a reduced incorporation of leucine due to addition of DFAA in these cultures

The significance of DCAA, DFAA and D-DNA as carbon sources to the bacteria was determined from the measured reduction in concentrations of DCAA and the assimilation rates of DFAA and D-DNA during the initial $24 \mathrm{~h}$. Incorporation of DCAA, DFAA and DDNA ranged from 1.69 (control) to $2.40 \mu \mathrm{g} \mathrm{Cl}^{-1} \mathrm{~h}^{-1}$ $\left(\mathrm{NH}_{4}{ }^{+} /\right.$DFAA-enriched cultures) (Table 2). Net carbon assimilation of DCAA, DFAA and D-DNA accounted for 41.9 to $59.8 \%$ of the net bacterial carbon production (Table 2). Incorporation of carbon from DCAA, DFAA and D-DNA during the initial $24 \mathrm{~h}$ incubation period is shown in Fig. 3. The average, relative incorporation of carbon from DCAA, DFAA and D-DNA was 13.2, 76.9 and $9.9 \%$, respectively.

Nitrogen budget. The nitrogen contribution from assimilation of DCAA, DFAA and D-DNA ranged from 0.79 to $1.40 \mu \mathrm{g} \mathrm{N} \mathrm{l}^{-1} \mathrm{~h}^{-1}$ (Table 2). The lowest and highest incorporation of DCAA, DFAA and D-DNA occurred in the control and the $\mathrm{NH}_{4}{ }^{+}$-enriched cultures, respectively. Including uptake of $\mathrm{NH}_{4}{ }^{+}$and release of $\mathrm{NO}_{3}{ }^{-}$in the nitrogen budget, a smaller nitrogen incorporation, especially in the $\mathrm{NH}_{4}{ }^{+} / \mathrm{DFAA}$-enriched cultures, was obtained due to release of $\mathrm{NO}_{3}^{-}$. Incorporation of organic nitrogen constituted from 111 to $219 \%$ of the estimated bacterial nitrogen production. Relative to the total net nitrogen budget, the incorporated nitrogen accounted for $48 \%\left(\mathrm{NH}_{4}{ }^{+}\right.$-enriched) and $203 \%\left(\mathrm{NH}_{4}{ }^{+} / \mathrm{DFAA}\right.$-enriched $)$ of the estimated bacterial nitrogen production (Table 2). The excess nitrogen uptake suggests that a portion of the assimilated nitrogen was released, as discussed later.

Incorporation of DCAA, DFAA and D-DNA nitrogen, uptake of $\mathrm{NH}_{4}{ }^{+}$and release of $\mathrm{NO}_{3}^{-}$are shown in Fig. 3. The average, relative incorporation of DCAA, DFAA and D-DNA nitrogen was $10.0,81.1$ and $8.9 \%$, respectively. In cultures enriched with $\mathrm{NH}_{4}{ }^{+}$and $\mathrm{NH}_{4}{ }^{+} /$DFAA, 23.1 and $13.3 \%$ of the bacterial nitrogen incorporation originated from $\mathrm{NH}_{4}{ }^{+}$.

\section{Flax Pond}

Abundance and production of bacteria. The number of bacteria in the different batch cultures increased from approximately $0.5 \times 10^{6}$ cells $\mathrm{ml}^{-1}$ at the start of the incubation, to between 3 and $4 \times 10^{6}$ cells $\mathrm{ml}^{-1}$ at $48 \mathrm{~h}$ (Fig. 4A). Only in the methylamine- and $\mathrm{NH}_{4}{ }^{+} /$methylamine-enriched cultures was a reduction 
Table 1. Santa Rosa Sound. Consumption of dissolved organic carbon (DOC), bacterial carbon production and bacterial growth efficiency. Average values $\left( \pm 1 . \mathrm{SD}\right.$ ) of the initial $24 \mathrm{~h}$ incubation period are shown. Initial DoC concentration was 3.520 mg $\mathrm{Cl} \mathrm{l}^{-1}$

\begin{tabular}{|c|c|c|c|c|}
\hline Experiment & 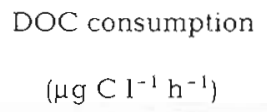 & $\begin{array}{l}\text { Bacterial C } \\
\text { production } \\
\left(\mu \mathrm{g} \mathrm{Cl}^{-1} \mathrm{~h}^{-1}\right)\end{array}$ & $\begin{array}{l}\text { Leucine-based } \\
\text { bacterial production } \\
\quad\left(\mu \mathrm{g} \mathrm{C}^{-1} \mathrm{~h}^{-1}\right)\end{array}$ & $\begin{array}{l}\text { Bacterial growth } \\
\text { efficiency } \\
(\%)\end{array}$ \\
\hline Control & $5.36 \pm 1.75$ & $3.56 \pm 0.30$ & $3.41 \pm 0.03$ & $38.0 \pm 7.1$ \\
\hline$+\mathrm{NH}_{4}^{+}$ & $6.88 \pm 1.63$ & $3.19 \pm 0.36$ & $3.31 \pm 0.16$ & $46.4 \pm 10.7$ \\
\hline+ DFAA & $11.46 \pm 2.67$ & $3.85 \pm 0.27$ & $1.85 \pm 0.04$ & $33.6 \pm 4.9$ \\
\hline$+\mathrm{NH}_{4}{ }^{+} / \mathrm{DFAA}$ & $10.00 \pm 2.75$ & $3.10 \pm 0.47$ & $2.58 \pm 0.74$ & $31.0 \pm 4.7$ \\
\hline \multicolumn{5}{|c|}{$\begin{array}{l}\text { Assuming a cell volume of } 0.05 \mu \mathrm{m}^{3}(t=0 \mathrm{~h}) \text { and } 0.15 \mu \mathrm{m}^{3}(t=24 \mathrm{~h}) \text { (Kroer unpubl.), and } 0.35 \times 10^{-12} \mathrm{~g} \mathrm{C}^{-3} \mathrm{~m}^{-3}(\mathrm{Bj} ø \mathrm{msen} 1986 \\
\text { Assuming that leucine (mol wt } 132.1) \text { made up } 8.5 \% \text { of bacterial proteins, that } 63 \% \text { of the bacterial dry weight was protei } \\
\text { and that } 54 \% \text { of the dry weight was carbon (Simon \& Azam 1989) } \\
\text { Bacterial carbon production as \% of DOC consumption }\end{array}$} \\
\hline
\end{tabular}

Table 2. Santa Rosa Sound. Net incorporation of C and N by assimilation of DCAA, DFAA and D-DNA relative to bacterial C and $\mathrm{N}$ production. Average values $( \pm 1 \mathrm{SD})$ of the initial $24 \mathrm{~h}$ incubation period are shown

\begin{tabular}{|c|c|c|c|c|c|c|}
\hline \multirow[t]{2}{*}{ Experiment } & \multirow[t]{2}{*}{$\begin{array}{l}\text { Net incorporation } \\
\text { of carbon } \\
\left(\mu g \mathrm{Cl}^{-1} \mathrm{~h}^{-1}\right)\end{array}$} & \multirow[t]{2}{*}{$\begin{array}{c}\text { Net C incorporation } \\
\text { as \% of bacterial C } \\
\text { production }{ }^{\mathrm{a}, \mathrm{b}} \\
(\%)\end{array}$} & $\begin{array}{r}\text { Net inc } \\
\text { of } n i\end{array}$ & $\begin{array}{l}\text { Net incorporation } \\
\text { of nitrogen }\end{array}$ & \multicolumn{2}{|c|}{$\begin{array}{c}\text { Net } \mathrm{N} \text { incorporation as } \\
\% \text { of bacterial } \mathrm{N} \\
\text { production } \\
(\%)\end{array}$} \\
\hline & & & Organic $N^{\circ}$ & Total $N^{c}$ & Organic $N^{d}$ & Total $N^{c}$ \\
\hline Control & $1.69 \pm 0.35$ & $53.1 \pm 5.5$ & $0.79 \pm 0.18$ & & $111 \pm 29$ & \\
\hline$+\mathrm{NH}_{4}{ }^{+}$ & $1.98 \pm 0.38$ & $44.0 \pm 9.8$ & $1.40 \pm 0.31$ & $1.30 \pm 0.33^{c}$ & $219 \pm 43$ & $203 \pm 33^{c}$ \\
\hline + DFAA & $1.99 \pm 0.24$ & $59.8 \pm 9.9$ & $0.95 \pm 0.14$ & & $123 \pm 25$ & \\
\hline$+\mathrm{NH}_{4}{ }^{+} / \mathrm{DFAA}$ & $2.40 \pm 0.31$ & $41.9 \pm 7.2$ & $1.15 \pm 0.20$ & $0.30 \pm 0.20^{\circ}$ & $185 \pm 42$ & $48 \pm 11^{c}$ \\
\hline \multicolumn{7}{|c|}{${ }^{3}$ Calculated as sum of individual contributions of DCAA, DFAA and D-DNA (Fig. 3) } \\
\hline \multicolumn{7}{|c|}{ b Assuming cell volumes of $0.05 \mu^{3}(t=0 \mathrm{~h})$ and $0.15 \mu^{3}(t=24 \mathrm{~h})$, and $0.35 \times 10^{-12} \mathrm{~g} \mathrm{Cum}^{-3}$ (Table 1) } \\
\hline \multirow{2}{*}{\multicolumn{7}{|c|}{$\begin{array}{l}\text { "Calculated as sum of individual contributions of DCAA, DFAA, D-DNA, } \mathrm{NO}_{3}{ }^{-} \text {and } \mathrm{NH}_{4}^{+} \text {(Fig. } 3 \text { ) } \\
{ }^{\mathrm{C}} \text { Bacterial } \mathrm{N} \text { production was determined from the bacterial } \mathrm{C} \text { production, assuming a } \mathrm{C} / \mathrm{N} \text { ratio of } 5: 1\end{array}$}} \\
\hline${ }^{\mathrm{d}}$ Bacterial N p & oduction was detern & ined from the bacteria & production, a & suming a $\mathrm{C} / \mathrm{N}$ & & \\
\hline
\end{tabular}

of the cell number (after $39 \mathrm{~h}$ ) observed. The cultures enriched with HMW-DOM had a higher initial abundance of bacteria than the other cultures, most likely due to bacteria concentrated in the ultrafiltration procedure. Incorporation of thymidine peaked in 4 of the cultures at $13 \mathrm{~h}$; in the control, $\mathrm{NH}_{4}{ }^{+}$- and $\mathrm{HMW}$ DOM-enriched cultures, the production increased for $26 \mathrm{~h}$ (Fig. 4B). From 39 to $52 \mathrm{~h}$, bacterial production increased again in some of the cultures.

DCAA. The concentration of DCAA increased slightly in four of the cultures during the initial $26 \mathrm{~h}$ (13 $\mathrm{h}$ in the glucose enriched-enriched cultures), after which the concentration declined (Fig. 4C) In the HMW-DOM-enriched cultures, the concentration of DCAA increased from 1760 to $2810 \mathrm{nM}$ at $13 \mathrm{~h}$ and then declined. In cultures to which $\mathrm{NH}_{4}^{+} /$-methylamine was added, the DCAA concentration decreased during most of the incubation period. Measurements of DCAA and DFAA (see below) were restricted to the first $39 \mathrm{~h}$, as bacterial carbon and nitrogen budgets only were based upon values from 0 to $26 \mathrm{~h}$.
DFAA. Concentrations of DFAA typically decreased from initial values of 180 to $220 \mathrm{nM}$ to values of 75 to $125 \mathrm{nM}$ after $39 \mathrm{~h}$ (data not shown). The assimilation of DFAA peaked at $13 \mathrm{~h}$, except for the HMW-DOM-and $\mathrm{NH}_{4}{ }^{+}$-enriched cultures, which reached a maximum at 26 h (Fig. 5A). The HMW-DOM-enriched cultures initially had a higher assimilation rate, probably due to the higher number of bacteria

D-DNA. The concentration of D-DNA increased from between 5 and $7 \mu \mathrm{I} \mathrm{I}^{-1}$ initially, to between 17 and $26 \mu \mathrm{g} \mathrm{l}^{-1}$ at $52 \mathrm{~h}$ (Fig. 5B). The highest concentrations were measured in the HMW-DOM-enriched cultures at $52 \mathrm{~h}$ (Fig. 5B). The assimilation rate of D-DNA generally increased during the incubation period; however, maximum assimilation in the methylamineand the $\mathrm{NH}_{4}{ }^{+} /$glucose-enriched cultures occurred at $26 \mathrm{~h}$ (Fig. 5C). An up to 3-fold larger D-DNA assimilation, relative to the other cultures, was measured in the HMW-DOM-enriched cultures at 26 and $52 \mathrm{~h}$.

Inorganic nitrogen. At the start of the experiment, concentrations of $\mathrm{NH}_{4}{ }^{+}$and $\mathrm{NO}_{3}{ }^{-}$in the cultures were 


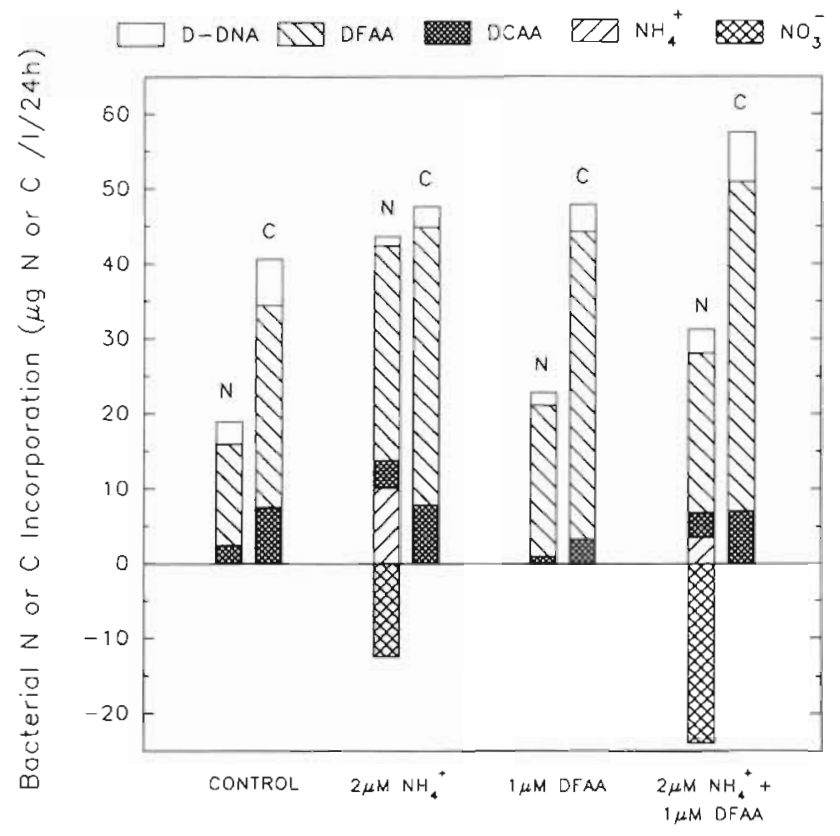

Fig. 3. Incorporation of nitrogen and carbon based on uptake of D-DNA, DFAA, DCAA, $\mathrm{NH}_{4}{ }^{+}$and $\mathrm{NO}_{3}{ }^{-}$Integrated values of the initial $24 \mathrm{~h}$ incubation period are shown. Negative values indicate a release

1.2 to $3.7 \mu \mathrm{M}$ and 0.4 to $2.1 \mu \mathrm{M}$, respectively, (Table 3 ). At $26 \mathrm{~h}, \mathrm{NH}_{4}{ }^{+}$was reduced in all cultures, with concentrations from $<0.1 \mu \mathrm{M}$ in the glucose- and the HMWDOM-enriched cultures, to $2.6 \mu \mathrm{M}$ in the methylamine/ $\mathrm{NH}_{4}{ }^{+}$-enriched cultures. The concentration of $\mathrm{NO}_{3}{ }^{-}$at $26 \mathrm{~h}$ increased in cultures to which $\mathrm{NH}_{4}{ }^{+}$was added; in the other cultures $\mathrm{NO}_{3}{ }^{-}$was reduced. At 38 and $52 \mathrm{~h}$, variable concentrations of $\mathrm{NH}_{4}{ }^{+}$and $\mathrm{NO}_{3}{ }^{-}$ occurred.

Concentrations of mono- (MMA), di- (DMA) and trimethylamine (TMA) were determined at 0, 14 and $46 \mathrm{~h}$. In cultures not amended with methylamines, initial concentrations of MMA, DMA and TMA were 50 , 185 and $35 \mathrm{nM}$, respectively. During the $46 \mathrm{~h}$ period, concentrations of MMA remained unchanged, while DMA and TMA increased by 110 and $25 \mathrm{nM}$, respectively. In the methylamine-amended cultures, MMA, DMA and TMA increased by 75, 410 and $80 \mathrm{nM}$, respectively, after which the concentrations declined. Details of methylamine dynamics in the cultures are given in Yang (1991).

Carbon budget. Bacterial carbon and nitrogen budgets were calculated for the first $26 \mathrm{~h}$ period when there was an actively growing population in all cultures (Fig. 4A). Consumption of DOC in the cultures varied between 4.62 and $7.31 \mu \mathrm{g} \mathrm{C} \mathrm{l}^{-1} \mathrm{~h}^{-1}$ (Table 4). The largest consumption was measured in the HMWDOM-enriched cultures. Particulate organic carbon (POC), representing the bacterial biomass, ranged

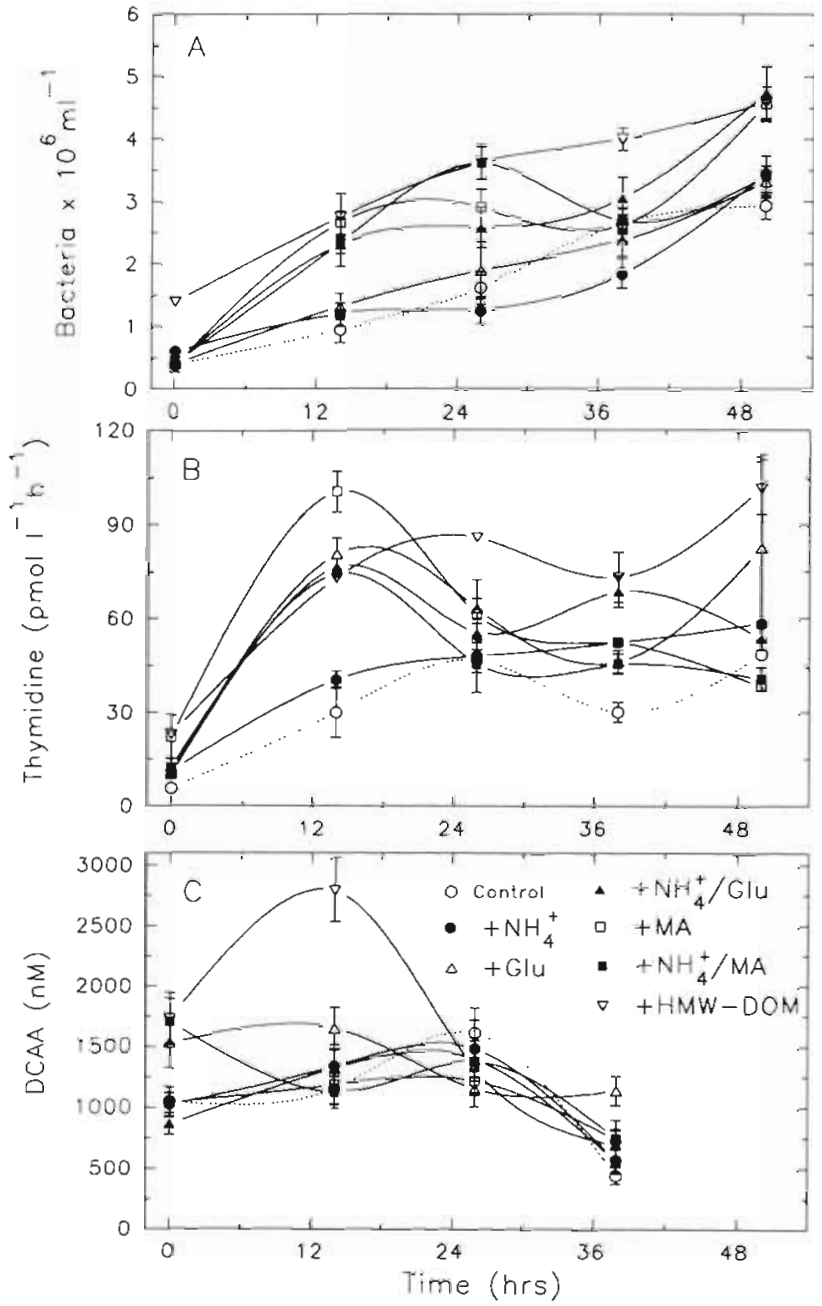

Fig. 4. Flax Pond. (A) Bacterial abundance, (B), incorporation of thymidine and (C) concentrations of dissolved combined amino acids (DCAA) in the batch cultures. Means $\pm 1 \mathrm{SD}$ ( $\mathrm{n}=4 ; 2$ from each batch) are shown. Additions: $1 \mu \mathrm{M} \mathrm{NH}_{4}{ }^{+}$ or glucose (Glu), $0.6 \mu \mathrm{M}$ mono-, di- and trimethylamines (MA) or $3 \times$ the natural concentration of high-molecular-weight dissolved organic matter (HMW-DOM)

from $1.65 \mu \mathrm{g} \mathrm{Cl}^{-1} \mathrm{~h}^{-1}$ in the $\mathrm{NH}_{4}{ }^{+}$-enriched cultures, to $3.04 \mu \mathrm{g} \mathrm{C} \mathrm{l}^{* 1} \mathrm{~h}^{-1}$ in the methylamine-enriched cultures. The growth efficiency of the bacteria, i.e. production of POC as percentage of consumed DOC, was 27.6 to $49.2 \%$.

Bacterial production, based on incorporation of thymidine, varied from 1.91 (control) to $4.19 \mu \mathrm{g} \mathrm{Cl}^{-1} \mathrm{~h}^{-1}$ (HMW-DOM-enriched cultures). Thymidine-based production on average was 1.40-fold larger than production based on POC.

Total net incorporation of carbon from assimilation of DCAA, DFAA and D-DNA ranged between 1.74 (control) to $3.22 \mu \mathrm{g} \mathrm{C} \mathrm{l}^{-1} \mathrm{~h}^{-1}$ (HMW-DOM-enriched cultures) (Table 5). Net incorporation of carbon from DCAA, DFAA and D-DNA sustained from $65.8 \%$ 

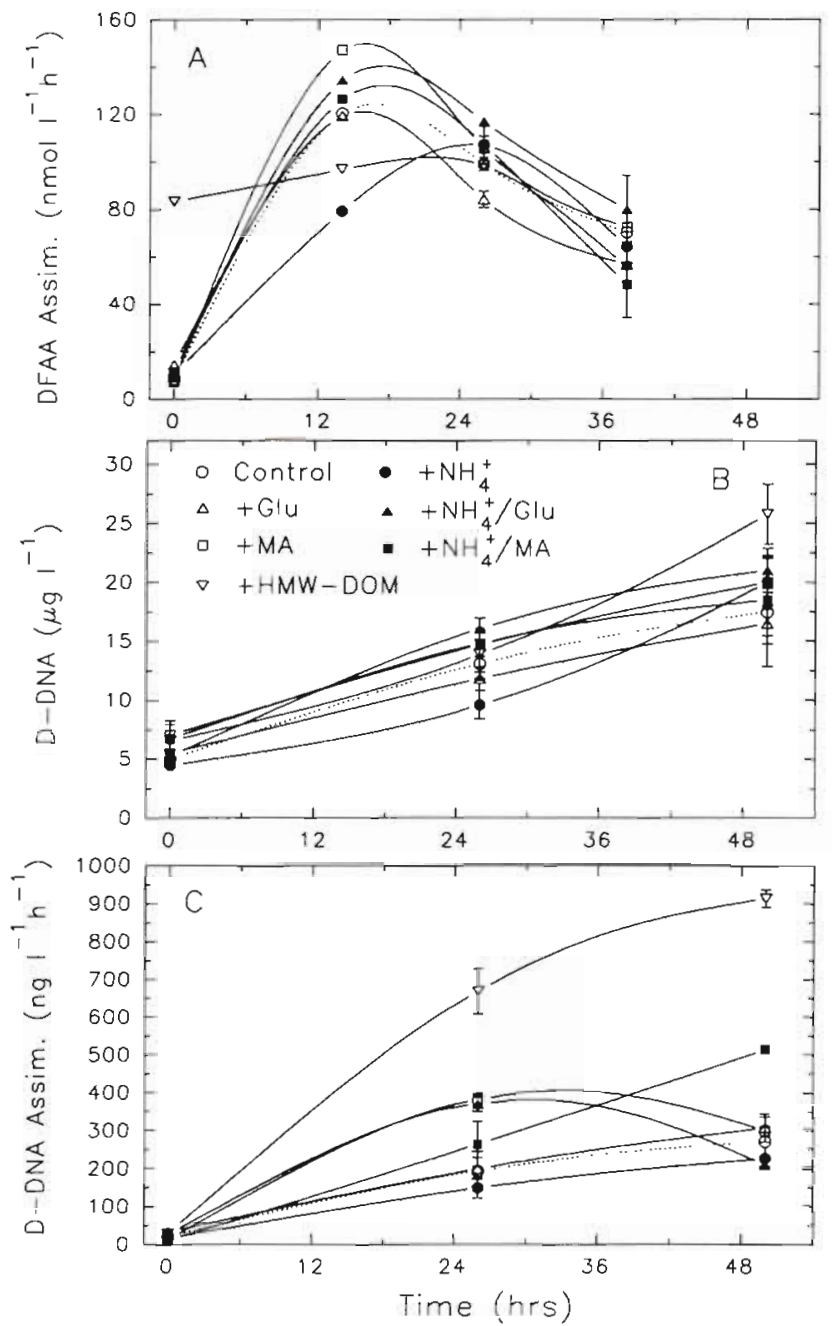

Fig. 5. Net assimilation of (A) DFAA and (C) D-DNA and (B) concentrations of D-DNA; otherwise as in Fig. 4

( $\mathrm{NH}_{4}{ }^{+}$-enriched cultures) to $91.3 \%$ (control) of the bacterial carbon production (calculated on basis of thymidine incorporation). The average value was $77 \%$.

Incorporation of carbon from DCAA, DFAA and DDNA during the first $26 \mathrm{~h}$ is illustrated in Fig. 6. On average DCAA, DFAA and D-DNA made up $75.9 \%$ of

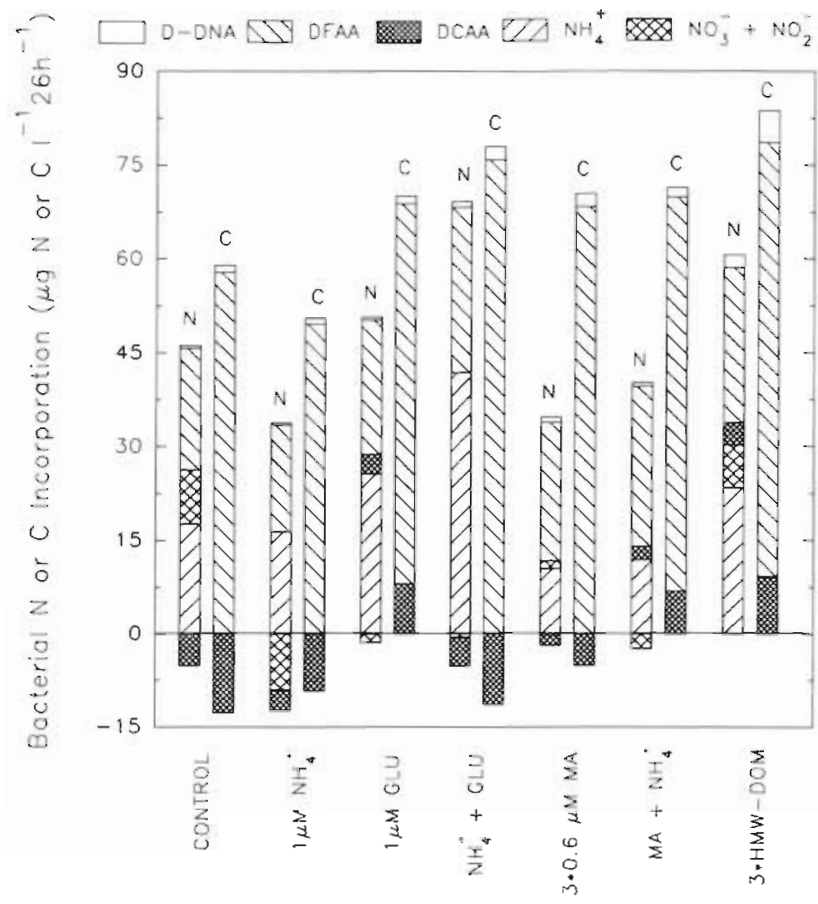

Fig. 6. Incorporation of nitrogen and carbon from uptake of D-DNA, DFAA, DCAA, $\mathrm{NH}_{4}^{+}$and $\mathrm{NO}_{2}^{-}+\mathrm{NO}_{3}^{-}$. Integrated values of the initial $27 \mathrm{~h}$ incubation period are shown. Negative values indicate a release

bacterial carbon production. DFAA were the dominant source of carbon. DCAA on average constituted - $3.1 \%$ [from $-27.6 \%$ (control) to $11.0 \%$ (HMW-DOM-enriched cultures)] of the DCAA, DFAA and D-DNA incorporation. The average incorporation of D-DNA made up $2.4 \%$ of the DCAA, DFAA and D-DNA incorporation. The release of DCAA and the low D-DNA incorporation imply that incorporation of DCAA, DFAA and D-DNA in terms of carbon largely was identical to the DFAA incorporation.

Nitrogen budget. Particulate organic nitrogen (PON) was measured in three of the cultures; produc-

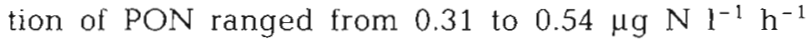
(Table 4). Thus, the $\mathrm{C} / \mathrm{N}$ ratios of the bacteria varied

Table 3. Concentrations of ammonium and nitrate in the Flax Pond cultures. MA: methylamines; HMW-DOM: high-molecularweight dissolved organic matter. Mean concentrations in $\mu \mathrm{M}$ shown

\begin{tabular}{|c|c|c|c|c|c|c|c|c|c|c|c|c|c|c|}
\hline \multirow[b]{2}{*}{$\mathrm{T}(\mathrm{h})$} & \multicolumn{2}{|c|}{ Control } & \multicolumn{2}{|c|}{$+\mathrm{NH}_{4}^{+}$} & \multicolumn{2}{|c|}{ + Glu } & \multicolumn{2}{|c|}{$+\mathrm{NH}_{4}+/ \mathrm{Glu}$} & \multicolumn{2}{|c|}{$+\mathrm{MA}$} & \multicolumn{2}{|c|}{$+\mathrm{MA} / \mathrm{NH}_{4}{ }^{+}$} & \multicolumn{2}{|c|}{$+\mathrm{HMW}-\mathrm{DOM}$} \\
\hline & $\mathrm{NH}_{4}^{+}$ & $\mathrm{NO}_{3}^{-}$ & $\mathrm{NH}_{4}{ }^{+}$ & $\mathrm{NO}_{3}^{-}$ & $\mathrm{NH}_{4}{ }^{+}$ & $\mathrm{NO}_{3}^{-}$ & $\mathrm{NH}_{4}{ }^{+}$ & $\mathrm{NO}_{3}^{-}$ & $\mathrm{NH}_{4}{ }^{+}$ & $\mathrm{NO}_{3}^{-}$ & $\mathrm{NH}_{4}^{+}$ & $\mathrm{NO}_{3}$ & $\mathrm{NH}_{4}{ }^{+}$ & $\mathrm{NO}_{3}{ }^{-}$ \\
\hline 0 & 1.8 & 2.1 & 2.6 & 0.8 & 1.9 & 0.4 & 3.7 & 0.6 & 1.9 & 0.6 & 3.0 & 0.5 & 1.2 & 1.7 \\
\hline 13 & 1.7 & 2.3 & 4.4 & 1.8 & 0.4 & 0.6 & 1.2 & 0.7 & 1.7 & 0.8 & 2.2 & 0.6 & 1.0 & 0.8 \\
\hline 26 & 0.6 & 1.3 & 1.5 & 1.3 & $<0.1$ & 0.5 & 0.7 & 1.6 & 1.2 & 0.5 & 2.6 & 0.6 & $<0.1$ & 0.1 \\
\hline 38 & 1.7 & 2.6 & 0.2 & 0.9 & 0.9 & 0.6 & 2.8 & 5.0 & 4.3 & 4.1 & 4.1 & 2.7 & 0.9 & 0.4 \\
\hline 50 & 2.8 & 3.8 & 3.0 & 6.1 & 2.5 & 2.3 & 0.8 & 1.2 & 2.1 & 1.9 & 3.7 & 2.8 & 1.2 & 1.6 \\
\hline
\end{tabular}


Table 4. Flax Pond. Consumption of dissolved organic carbon (DOC), production of particulate organic carbon (POC) and nitrogen (PON) and bacterial carbon production based on incorporation of thymidine. Average values ( \pm 1 SD) of the initial $26 \mathrm{~h}$ incubation period are shown. Initial DOC concentration was $2.53 \mathrm{mg} \mathrm{1^{-1 }}$, except in the HMW-DOM-enriched cultures, in which $3.05 \mathrm{mg} \mathrm{l}^{-1}$ DOC occurred at start. MA: methylamines; HMW-DOM: high-molecular-weight dissolved organic matter. nd: no data

\begin{tabular}{|c|c|c|c|c|c|c|c|}
\hline Experiment & $\begin{array}{c}\text { DOC } \\
\text { consumption } \\
\left(\mu g C \mathrm{l}^{-1} \mathrm{~h}^{-1}\right)\end{array}$ & $\begin{array}{c}\mathrm{POC}^{d} \\
\left(\mu g C \mathrm{l}^{-1} \mathrm{~h}^{-1}\right)\end{array}$ & $\begin{array}{l}\text { Growth } \\
\text { efficiency } \\
(\%)\end{array}$ & $\begin{array}{c}\mathrm{PON}^{4} \\
\left(\mu \mathrm{g} \mathrm{N}^{-1} \mathrm{~h}^{-1}\right)\end{array}$ & $\begin{array}{l}C / N \\
\text { ratió }\end{array}$ & $\begin{array}{c}\text { Bacterial carbon } \\
\text { production d, } \\
\left(\mu \mathrm{gCl}^{-1} \mathrm{~h}^{-1}\right)\end{array}$ & $\begin{array}{c}\text { Growth } \\
\text { efficiency } \\
(\%)\end{array}$ \\
\hline Control & nd ${ }^{\bullet}$ & nd & -- & nd & - & $1.91 \pm 0.37$ & - \\
\hline$+\mathrm{NH}_{4}^{+}$ & $6.00 \pm 1.50$ & 1.65 & $27.6 \pm 5.5$ & 0.35 & 4.8 & & $40.1 \pm 12.1$ \\
\hline + Glucose & nd. & 1.77 & - & 0.31 & 5.8 & & - \\
\hline$+\mathrm{NH}_{4}{ }^{+} /$Glucose & $5.38 \pm 1.96$ & 2.50 & $46.4 \pm 12.4$ & nd & - & 3.46 & $64.3 \pm 23.8$ \\
\hline$+\mathrm{MA}$ & nd $\cdot$ & & - & 0.54 & 5.6 & & - \\
\hline$+\mathrm{MA}+\mathrm{NH}_{4}^{+}$ & $4.62 \pm 1.35$ & 2.27 & $49.2 \pm 11.1$ & $n$ & - & 6 & $65.7 \pm 20.1$ \\
\hline + HMW-DOM & $7.31 \pm 1.81$ & 2.58 & $35.3 \pm 7.0$ & nd & - & $4.19 \pm 0.38$ & $57.4 \pm 15.1$ \\
\hline \multicolumn{8}{|c|}{$\begin{array}{l}\text { a No replicates were measured. Typical analytical precision is } 9 \% \\
\text { b Produced POC as percentage of consumed DOC } \\
{ }^{c} \text { POC relative to PON } \\
\text { d Based on thymidine incorporation, assuming a conversion factor of } 1.1 \times 10^{18} \text { cells mol thymidine } \\
\text { e The average bacterial C content was } 3.5 \times 10^{-14} \mathrm{~g} \mathrm{C} \text { per bacterium, determined from production of POC and bacterial } \\
\text { abundance. This corresponds to a cell volume of } 0.10 \mu \mathrm{m}^{3} \text {, assuming } 0.35 \times 10^{-12} \mathrm{~g} \mathrm{C} \mu \mathrm{m}^{-3} \text { (Bjørnsen 1986) } \\
\text { ' Bacterial C production based on thymidine incorporation as percentage of consumed DOC } \\
\text { - No DOC determined due to instrumental problems }\end{array}$} \\
\hline
\end{tabular}

between $4.8\left(\mathrm{NH}_{4}{ }^{+}\right.$-enriched) and $5.8\left(\mathrm{NH}_{4}{ }^{+} /\right.$glucoseenriched). Net incorporation of nitrogen from DCAA, DFAA and D-DNA ranged from 0.57 (control) to $1.15 \mu \mathrm{g}$ $\mathrm{N}^{-1} \mathrm{~h}^{-1}$ (HMW-DOM-enriched cultures) (Table 5). The net nitrogen incorporation from DCAA, DFAA and D-DNA was $100 \%$ (methylamine-enriched) to $180 \%$ (methylamine/- $\mathrm{NH}_{4}{ }^{+}$-enriched) of net bacterial nitrogen production. Including uptake of $\mathrm{NH}_{4}{ }^{+}$and $\mathrm{NO}_{3}{ }^{-}$in the budgets, bacterial net incorporation ranged from $155 \%$ (methylamine-enriched) to $413 \%$ (control) (Table 5). Methylamine fluxes are not included in the nitrogen budgets since the methylamine sampling times did not coincide with the other sampling times.

Net incorporation of nitrogen from uptake or release of DCAA, DFAA, D-DNA, $\mathrm{NH}_{4}{ }^{+}$and $\mathrm{NO}_{3}{ }^{-}$during the first $26 \mathrm{~h}$ is shown in Fig. 6 . In 3 cultures $\left(\mathrm{NH}_{4}{ }^{+}\right.$, , methylamine- and methylamine/ $\mathrm{NH}_{4}{ }^{+}$-enriched), DFAA were the major single nitrogen source, making up 50.3 to $73.5 \%$ of the net $\mathrm{N}$ incorporation. In the remaining 4 cultures, DFAA and $\mathrm{NH}_{4}{ }^{+}$were of equal importance as nitrogen sources; together they made up 80.1 to $98.8 \%$ of net nitrogen incorporation. D-DNA and $\mathrm{NO}_{3}^{-}$

Table 5. Flax Pond. Net incorporation of $\mathrm{C}$ and $\mathrm{N}$ from assimilation of DCAA, DFAA and DNA relative to bacterial $\mathrm{C}$ and $\mathrm{N}$ production. Average values $( \pm 1 \mathrm{SD})$ of the initial $26 \mathrm{~h}$ incubation period are shown. MA: methylamines; HMW-DOM: highmolecular-weight dissolved organic matter

\begin{tabular}{|c|c|c|c|c|c|c|}
\hline \multirow[t]{2}{*}{ Experiment } & \multirow{2}{*}{$\begin{array}{l}\text { Net incorporation } \\
\text { of carbon }{ }^{\alpha} \\
\left(\mu g \mathrm{Cl}^{-1} \mathrm{~h}^{-1}\right)\end{array}$} & \multirow{2}{*}{$\begin{array}{c}\text { Net } C \text { incorporation } \\
\text { as \% of bacterial C } \\
\text { production }^{b} \\
(\%)\end{array}$} & \multicolumn{2}{|c|}{$\begin{array}{l}\text { Net incorporation } \\
\text { of nitrogen }\end{array}$} & \multirow[t]{2}{*}{$\begin{array}{c}\text { Organic net } N \\
\text { incorporation as } \\
\% \text { of bacterial N } \\
\text { production }{ }^{c} \\
(\%)\end{array}$} & \multirow{2}{*}{$\begin{array}{c}\text { Total net } \mathrm{N} \\
\text { incorporation as } \\
\% \text { bacterial } \mathrm{N} \\
\text { production }^{\mathrm{d}} \\
(\%)\end{array}$} \\
\hline & & & Organic $N^{a}$ & Total $N^{d}$ & & \\
\hline Control & $1.74 \pm 0.57$ & $91.3 \pm 34.9$ & $0.57 \pm 0.19$ & $1.58 \pm 0.20$ & $148 \pm 44$ & $413 \pm 97$ \\
\hline$+\mathrm{NH}_{4}^{+}$ & $1.58 \pm 0.43$ & $65.8 \pm 21.1$ & $0.54 \pm 0.15$ & $0.82 \pm 0.17$ & $113 \pm 36$ & $171 \pm 55$ \\
\hline + Glucose & $2.70 \pm 1.06$ & $77.0 \pm 28.6$ & $0.97 \pm 0.28$ & $1.90 \pm 0.31$ & $138 \pm 28$ & $271 \pm 37$ \\
\hline$+\mathrm{NH}_{4} \div /$ Glucose & $2.56 \pm 0.44$ & $73.9 \pm 13.7$ & $0.87 \pm 0.15$ & $2.67 \pm 0.19$ & $125 \pm 26$ & $354 \pm 42$ \\
\hline$+M A$ & $2.52 \pm 0.70$ & $62.3 \pm 18.0$ & $0.77 \pm 0.33$ & $1.25 \pm 0.30$ & $100 \pm 28$ & $155 \pm 29$ \\
\hline$+\mathrm{MA} / \mathrm{NH}_{4}{ }^{+}$ & $2.75 \pm 0.90$ & $90.6 \pm 31.7$ & $1.09 \pm 0.32$ & $1.45 \pm 0.37$ & $180 \pm 47$ & $240 \pm 49$ \\
\hline + HMW-DOM & $3.22 \pm 0.49$ & $76.8 \pm 13.6$ & $1.17 \pm 0.17$ & $2.33 \pm 0.23$ & $139 \pm 24$ & $278 \pm 32$ \\
\hline \multicolumn{7}{|c|}{ a Calculated as sum of individual contributions of DCAA, DFAA and D-DNA (Fig. 6) } \\
\hline \multicolumn{7}{|c|}{ Bacterial C production based on incorporation of thymidine (Table 4) } \\
\hline \multicolumn{7}{|c|}{ 'Bacterial N production based on incorporation of thymidine, assuming a $\mathrm{C} / \mathrm{N}$ ratio of $5: 1$ (Table 4) } \\
\hline d Calculated as $\mathrm{s}$ & sum of individual $\mathrm{c}$ & ntributions of DCAA, & DFAA, D-DN & $\mathrm{A}, \mathrm{NO}_{3}{ }^{-}$and $\mathrm{N}$ & $\mathrm{L}_{4}^{+}$(Fig. 6) & \\
\hline
\end{tabular}


were of little importance as nitrogen sources, corresponding to less than $5 \%$ of the nitrogen incorporation.

\section{DISCUSSION}

Results from the SRS and FP batch cultures indicated that DFAA were a significant source of bacterial carbon and that DFAA and $\mathrm{NH}_{4}{ }^{+}$were significant sources of nitrogen. DCAA and D-DNA were of less importance as nutrients to the bacteria.

\section{Carbon and nitrogen flux in SRS cultures}

Bacterial carbon production in the SRS cultures was only moderately influenced by the enrichment with DFAA and $\mathrm{NH}_{4}{ }^{+}$. The DFAA amendment corresponded to $63 \mu \mathrm{g} \mathrm{Cl}^{-1}$, i.e. a carbon source for bacterial production almost as large as that actually measured, 74 to $93 \mu \mathrm{g} \mathrm{C} \mathrm{l}^{-1} 24 \mathrm{~h}^{-1}$. But bacterial production in cultures to which DFAA were added was only higher than the control in one set of cultures. Similarly, addition of $\mathrm{NH}_{4}{ }^{+}$did not have a stimulatory effect on the bacterial carbon production. These results suggest that the bacteria were neither limited by carbon nor by nitrogen. However, the reduced effect of DFAA addition may be caused by a high initial DFAA respiration, as was observed in other studies of SRS bacteria la $90 \%$ DFAA respiration was measured within an initial $18 \mathrm{~h}$ growth period; Jørgensen et al. unpubl. data). The slightly stimulated growth in the cultures may also indicate that the bacteria were limited by other substances, e.g. phosphorus. In the other studies of SRS bacteria mentioned above, addition of phosphate significantly increased bacterial growth.

Incorporation of DFAA, DCAA and D-DNA met about half of the carbon requirement of the bacteria. Most of the measured carbon flux was due to DFAA, which made up $77 \%$ of the incorporation. DCAA were relatively most important as carbon sources in the cultures that had not been enriched with DFAA, but DCAA on the average constituted only about $10 \%$ of the DCAA, DFAA and D-DNA carbon incorporation. A similar value was found for D-DNA. The nitrogen flux of the bacteria was influenced by the lack of inorganic nitrogen $\left(\mathrm{NH}_{4}{ }^{+}\right)$in 2 of the cultures. $\mathrm{NH}_{4}{ }^{+}$was taken up in the $\mathrm{NH}_{4}{ }^{+}$-enriched cultures, but due to production of $\mathrm{NO}_{3}{ }^{-}$, the inorganic nitrogen balance in these cultures was negative. In all cultures, nitrogen assimilation of DCAA, DFAA and D-DNA sustained $100 \%$ or more of the bacterial nitrogen demand. When uptake of $\mathrm{NH}_{4}{ }^{+}$and release of $\mathrm{NO}_{3}{ }^{-}$are included in the bacterial nitrogen balance, about half $\left(\mathrm{NH}_{4}{ }^{+} / \mathrm{DFAA}\right.$ enriched) or 2 times $\left(\mathrm{NH}_{4}{ }^{+}\right.$-enriched) the bacterial ni- trogen production could be accounted for. The discrepancy between incorporated and produced nitrogen will be discussed later.

\section{Carbon and nitrogen flux in FP cultures}

Bacterial production significantly increased in the FP experiment when the cultures were enriched with various nitrogen and carbon compounds. Observed changes in bacterial production in 4 of the 6 enriched cultures suggested that the bacteria were limited by carbon rather than nitrogen: addition of $\mathrm{NH}_{4}{ }^{+}$slightly increased the production, but addition of glucose, methylamines, or both $\mathrm{NH}_{4}{ }^{+}$and glucose almost doubled the production (Table 4). HMW-DOM, which increased the DOC concentration by $20 \%$, had an even more pronounced effect, as the growth went up 2.2-fold.

DFAA were the dominant carbon source to the bacteria, while DFAA and $\mathrm{NH}_{4}{ }^{+}$were the major nitrogen sources. DCAA were assimilated in 3 cultures, but released in 4 cultures. D-DNA was insignificant as a carbon and nitrogen source, making up $2.4 \%(C)$ and $5 \%$ (N) of the DCAA, DFAA and D-DNA incorporation. The average net carbon incorporation corresponded to $76 \%$ of the bacterial production. The larger DFAA incorporation in the glucose- and HMW-DOM-enriched cultures relative to the control cultures, may be caused by an additional energy supply from glucose resulting in greater protein synthesis (Kirchman 1990) and an exoenzymatic release of DFAA from degradation of HMW-DOM, enabling a higher incorporation of DFAA into proteins. The cause of the higher DFAA incorporation in the methylamine-enriched cultures is uncertain, but it is known that methylamines can be a source of both carbon and nitrogen to heterotrophic bacteria (discussed later). Since the bacterial growth was not limited by nitrogen (addition of $\mathrm{NH}_{4}{ }^{+}$did not stimulate the bacterial production), methylamines and DFAA speculatively may have provided (1) carbon and (2) nitrogen and energy, respectively, for biosynthetic purposes.

The nitrogen budgets indicate that DFAA and $\mathrm{NH}_{4}{ }^{+}$ were the major bacterial nitrogen sources. In 3 cultures, DFAA made up more than $50 \%$ of the DCAA, DFAA, D-DNA, $\mathrm{NH}_{4}{ }^{+}$and $\mathrm{NO}_{3}{ }^{-}$utilization. In the remaining cultures, DFAA and $\mathrm{NH}_{4}{ }^{+}$were similar in importance as nitrogen sources and together they made up 80 to $99 \%$ of the bacterial nitrogen incorporation. D-DNA and $\mathrm{NO}_{3}^{-}$were insignificant as nitrogen sources, comprising less than $5 \%$ of the nitrogen incorporation. $\mathrm{NO}_{3}{ }^{-}$was released in 3 cultures, showing that nitrifying bacteria were present in the cultures. The experiment illustrates that actively growing bacteria 
can utilize both inorganic and organic nitrogen. When the nitrogen incorporation was related to bacterial production, the measured compounds sustained more than $100 \%$ of the bacterial nitrogen production (Table 5). This will be discussed later.

\section{Significance of specific compounds}

DFAA. Incorporation of DFAA carbon has been found to sustain 5 to $24 \%$ (oceanic waters; Simon 1991) and 1 to $69 \%$ (freshwater; Simon \& Rosenstock 1992; Jørgensen 1992b) of the bacterial carbon production. In the present cultures DFAA carbon on the average contributed $39 \%$ (SRS) to $76 \%$ (FP) to the bacterial carbon production. During the initial 24 or $26 \mathrm{~h}$ periods of the 2 experiments, DFAA incorporation was 1.2 $\mu \mathrm{mol} \mathrm{l} \mathrm{l}^{-1} 24 \mathrm{~h}^{-1}$ (SRS) and $3.6 \mu \mathrm{mol} \mathrm{l}^{-1} 26 \mathrm{~h}^{-1}$ (FP). But measured reductions of the DFAA pool were only 100 to $200 \mathrm{nM}$, except in the DFAA-enriched experiments. This might suggest that the main source of the incorporated DFAA was peptides and proteins liberated by exoenzymatic activity. Changes in concentrations of DCAA in the cultures, however, were less than 1.2 to $3.6 \mu \mathrm{mol} \mathrm{l}^{-1}$ during the initial period of the experiments. One possible explanation is that a portion of the measured DFAA flux was released from some of the bacteria, and then reincorporated by other bacteria. If so, the presently measured DFAA incorporation overestimated the DFAA flux, since we assumed all amino acids to be of extracellular origin.

In previous studies, the significance of DFAA as a nitrogen source to marine bacteria has varied. In oceanic samples, DFAA have been found to sustain from 8 to $37 \%$ of the bacterial nitrogen demand (Simon 1991). In natural or enriched bacterial cultures, values from 22 to $76 \%$ (Goldman \& Dennett 1991) and from 14 to $246 \%$ (Keil \& Kirchman 1991a) have been measured. In our cultures, the calculated incorporation of organic nitrogen (mainly DFAA) was 0 to $119 \%$ larger than the bacterial nitrogen production. Keil \& Kirchman (1991a) suggested that this discrepancy between incorporated and bacterially produced nitrogen might be ascribed to incorrect biovolume conversion factors or to 'luxurious' nitrogen uptake. However, the $\mathrm{C} / \mathrm{N}$ ratios of FP bacteria (4.8 to 5.8 ) are within the expected range for ratios of marine bacteria (Goldman \& Dennett 1991), and the bacterial volumes used seem reasonable when related to the other bacterial measurements. Another explanation for the high nitrogen consumption may be an unmeasured release or conversion of organic or inorganic nitrogen compounds. Since we did not include such a release or conversion in the nitrogen budgets, the calculated net nitrogen incorporation rates may be overestimates. One potential group of compounds that might be released is the methylamines. During the FP experiments, DMA increased by 110 to $410 \mathrm{nM}$, and MMA and TMA increased by $80 \mathrm{nM}$ within the initial 2 d. In addition, Pedersen et al. (1993) have recently shown that in marine sediments, up to $80 \%$ of the ammonium production may originate in microbial hydrolysis of bacterially produced urea. Release of nitrogen in our cultures, e.g. from DFAA, would probably be mainly $\mathrm{NH}_{4}{ }^{+}$. If production of $\mathrm{NH}_{4}{ }^{+}$was delayed due to a transient urea production, it might cause the temporary appearance of a large nitrogen incorporation. This is presently being studied.

DCAA. Bacterial incorporation of DCAA carbon made up less than $10 \%$ of the measured incorporation of DCAA, DFAA and D-DNA. In the FP experiment, DCAA were released in 4 cultures. The DCAA concentrations measured in both experiments agree well with concentrations typically measured in coastal waters (Coffin 1989, Keil \& Kirchman 1991b).

Bacteria may have a significant capacity for utilization of DCAA. Hollibaugh \& Azam (1983) observed that bacterial assimilation of proteins could be similar to that of leucine. In an estuary, turnover times of ${ }^{14} \mathrm{C}$ labelled algal proteins were 4 to $180 \mathrm{~h}$ (Coffin 1989). Unfortunately, in none of these studies was protein utilization related to bacterial growth. The fate of DCAA taken up by bacteria in the present cultures was not examined. In other studies, most of the DCAA nitrogen was released as $\mathrm{NH}_{4}{ }^{+}$(Tupas \& Koike 1990). In our experiments there was a production of $\mathrm{NO}_{3}{ }^{-}$in the $\mathrm{NH}_{4}{ }^{+}$-enriched cultures, but only a minor portion of this could originate from the rather small DCAA uptake (Fig. 3)

The increase in DCAA in four of the FP cultures may be due to bacterial release of peptides or proteins. In chemostat cultures of bacteria, extracellular proteins have been found to accumulate when certain inorganic substances were limited (Neijssel \& Tempest 1975, Tempest \& Neijssel 1978). The proteins may have been located in the periplasmic space or in the outer cell membrane. Mechanisms causing release of proteins in our cultures are unknown. But since increasing concentrations of DCAA occurred in most of the cultures for different time intervals during the incubation period, release of DCAA by marine bacteria may be common. Caution must be taken in interpreting DCAA results, however, since colloidal and complexed amino acids not present as peptides and protein are also measured as DCAA.

D-DNA. Incorporation of D-DNA corresponded to only $2 \%$ (FP) and $5 \%$ (SRS) of the net bacterial carbon production in the cultures. The measured concentrations of D-DNA of 3 to $6 \mu \mathrm{g} \mathrm{l}^{-1}$ (SRS) and 4 to $27 \mu \mathrm{g} \mathrm{l}^{-1}$ (FP) fall within ranges measured previously in freshwater and marine environments (DeFlaun et al. 1987. 
Paul et al. 1987, 1989, Bailiff \& Karl 1991). The observed increase of the D-DNA concentration during active bacterial growth in the Flax Pond cultures agrees with observations by Paul et al. (1990), who found that active bacterioplankton were the dominant producers of D-DNA in freshwater.

Turnover times of D-DNA in our cultures of 4.9 to $10.4 \mathrm{~h}$ (SRS) and 15.3 to $232 \mathrm{~h}$ (FP) agree well with measured turnover times of 6.5 to $10.4 \mathrm{~h}$ or more of Escherichia coli and phage lambda $\left[{ }^{3} \mathrm{H}\right] \mathrm{DNA}$ in natural waters (Paul et al. 1987, 1989). Uptake of added $\left[{ }^{3} \mathrm{H}\right] \mathrm{DNA}$ probably differs from uptake of natural $\mathrm{D}$ DNA, e.g. due to differences in molecular size. The size of natural D-DNA has been found to range from 0.12 to 35.2 kilo-basepairs (kB) (Deflaun et al. 1987); the size of the presently used $\left[{ }^{3} \mathrm{H}\right] \mathrm{DNA}$ was not determined. The fate of D-DNA taken up by bacteria is uncertain. Some studies indicate that D-DNA is salvaged into nucleic acids (Paul et al. 1988) rather than being degraded and used as a source, e.g. phosphate (Paul \& Pichard 1989). However, in marine samples faster degradation of D-DNA has been found in P-limited than in P-nonlimited waters (Turk et al. 1992).

Uptake of D-DNA corresponded to about $10 \%$ of the incorporation of DFAA, DCAA and D-DNA nitrogen. D-DNA contains $16 \%$ nitrogen and thus is a potential source of nitrogen to the bacteria. Regardless of whether D-DNA is mineralized or salvaged for production of new DNA, D-DNA may still contribute to the nitrogen metabolism of the cells.

Methylamines. Methylamines can serve as either a carbon or nitrogen source to many heterotrophic bacteria (Large 1981). Their use by nitrifying and $\mathrm{N}_{2}$-fixing bacteria appears to be primarily under conditions of nitrogen-limitation and addition of $\mathrm{NH}_{4}{ }^{+}$limits their uptake (Glover 1982, Mazzucco \& Benson 1984). However, in our cultures addition of $\mathrm{NH}_{4}{ }^{+}$to methylamine-enriched cultures did not influence the bacterial utilization of methylamines (Yang 1991), suggesting that methylamine uptake was not due to nitrifyers or nitrogen fixers. Bacterial turnover of $\left[{ }^{14} \mathrm{C} \mid\right.$ methylamines in the methylamine-enriched cultures indicated a nitrogen incorporation of about $8 \mu \mathrm{g} \mathrm{N} \mathrm{l^{-1 }}$ $26 \mathrm{~h}^{-1}$ (Yang 1991), corresponding to 20 to $25 \%$ of the total net nitrogen incorporation in these cultures. Methylamine nitrogen may in combination with DFAA carbon have been used for bacterial biosynthesis. The relatively low incorporation of both $\mathrm{NH}_{4}{ }^{+}$and DFAA nitrogen in the methylamine-enriched cultures (Fig. 6) supports the significance of methylamine as a nitrogen source. In addition to heterotrophic bacteria, methylotrophic bacteria, e.g. Hyphomicrobium, which is widespread in marine waters, are known to utilize methylamines (Brock \& Madigan 1991). Generally, however, the effect of methylamines on microbial growth appears to be complex. In studies of oceanic waters methylamines together with putrescine were found to stimulate bacterial growth, but when in addition $\mathrm{NH}_{4}{ }^{+}$was added, no stimulation occurred (Kirchman 1990).

High-molecular-weight DOM. The cultures enriched with HMW-DOM had the largest assimilation of D-DNA and a high assimilation of DCAA. Simultaneously, there was a relatively high uptake of ammonium and nitrite/nitrite (Fig. 6). This may indicate that incorporation of D-DNA and DCAA carbon was accompanied by uptake of $\mathrm{NH}_{4}{ }^{+}$- and $\mathrm{NO}_{3}{ }^{-} \mathrm{N}$ to obtain an appropriate $\mathrm{C} / \mathrm{N}$ ratio for biosynthetic purposes. Composition of the HMW-DOM was not examined, but concentrations of DCAA and D-DNA in the HMWDOM-enriched cultures were only slightly higher than in the other cultures. Studies have shown that most of the nitrogen in HMW-DOM is amino-nitrogen, while amino acids may contribute only 10 to $20 \%$ to the carbon content (Sigleo et al. 1983). Our results indicate that neither DCAA nor D-DNA were major constituents of the HMW-DOM.

$\mathrm{NH}_{4}{ }^{+}$and glucose. In marine bacteria, $\mathrm{NH}_{4}{ }^{+}$has been reported to sustain from 22 to $88 \%$ of the bacterial $N$ demand (Tupas \& Koike 1990, Goldman \& Dennett 1991). $\mathrm{NH}_{4}{ }^{+}$uptake has been shown to increase when an organic carbon source such as glucose or DFAA is available (Goldman \& Dennett 1991, Keil \& Kirchman 1991a). In our experiments, addition of glucose (FP cultures), but not DFAA (SRS cultures), stimulated $\mathrm{NH}_{4}{ }^{+}$uptake. Probably DFAA in the SRS cultures provided both carbon and nitrogen to the bacteria. When uptake or release of inorganic nitrogen $\left(\mathrm{NH}_{4}{ }^{+}\right.$and $\left.\mathrm{NO}_{3}{ }^{-}\right)$was considered in the present nitrogen budgets, an apparently excessive nitrogen incorporation still occurred in most cultures. A similar observation was made by Keil \& Kirchman (1991a) who found that in oceanic samples, uptake of $\mathrm{NH}_{4}{ }^{+}$could support up to $240 \%$ of the bacterial nitrogen production. As discussed above, this unrealistic nitrogen incorporation most likely was caused by release of organic nitrogen compounds.

Conversion factors. Calculation of the present bacterial carbon and nitrogen budgets involved several conversion factors, each of which may bias the carbon and nitrogen fluxes. In both experiments, constraints on the applied factors could be determined from the measurements of POC, DOC and to some extent PON Relating the consumed DOC to size-determined carbon production (SRS) or production of POC (FP), the bacterial growth efficiency was determined to be 28 to $49 \%$ (Tables $1 \& 4$ ). When the bacterial growth efficiency in Flax Pond was related to the thymidinebased carbon production, values of 40 to $66 \%$ were determined (Table 4 ). These growth efficiencies (28 to 
$66 \%$ ) fall within published values (Goldman \& Dennett 1991, Middelboe et al. 1992, Kroer 1993). For calculation of carbon budgets in the FP cultures, the thymidine-based values were used, as no POC values of the control cultures were available. The POC values on the average were $33 \%$ below the thymidine-based production values. The assumed $\mathrm{C} / \mathrm{N}$ ratio of $5: 1$ for calculation of the bacterial nitrogen production agreed with the measured $\mathrm{C} / \mathrm{N}$ ratios of 4.8 to 5.8 in the FP cultures (Table 4). These values are within $\mathrm{C} / \mathrm{N}$ ratios measured in mixed populations of marine bacteria (Bratbak 1985 , Kogura \& Koike 1987).

Conclusions. DFAA were found to be an important carbon source to marine bacteria, sustaining from $32 \%$ (SRS cultures) to $91 \%$ (FP cultures) of the bacterial carbon demand. DCAA and D-DNA were both minor nutrients to the bacteria and typically met less than $5 \%$ of their carbon demand. Dominant bacterial nitrogen sources were DFAA (primary nitrogen source in the SRS cultures) and $\mathrm{NH}_{4}{ }^{+}$, while $\mathrm{NO}_{3}{ }^{-}, \mathrm{D}$-DNA and DCAA were less significant contributors of nitrogen. The observed apparent excessive nitrogen assimilation, relative to the bacterial nitrogen production, probably was caused by release of organic nitrogen compounds, such as the methylamines.

Acknowledgements. The authors thank R. E. Jensen, $\mathrm{S}$. Pendosa, and X.-C. Wang for their invaluable assistance during field and laboratory work. T. Barkay kindly provided E. coli DNA. The project was supported by NATO (Collaborative Research Grant CRG 900536 to N.O.G.J.).

\section{LITERATURE CITED}

Bailiff, M. D., Karl, M. D. (1991). Dissolved and particulate DNA dynamics during a spring bloom in the Antarctic Peninsula region, 1986-87 Deep Sea Res, 38: $1077-1095$

Bjørnsen, P. K. (1986). Automatic determinations of bacterioplankton biomass by image analysis. Appl. environ. Microbiol. 51: 1199-1204

Bratbak, G. (1985). Bacterial biovolume and biomass estimations. Appl. environ. Microbiol. 49: 1488-1493

Brock, T D., Madigan, M. T. (1991). Biology of microorganisms. Prentice-Hall International, Inc., Englewood Cliffs, NJ, p. 738

Coffin, R. B. (1989). Bacterial uptake of dissolved free and combined amino acids in estuarine waters. Limnol. Oceanogr. 34: 531-542

DeFlaun, M. F., Paul, J. H., Jeffrey, W. H. (1987). Distribution and molecular weight of dissolved DNA in subtropical estuarine and oceanic environments. Mar. Ecol. Prog. Ser. 38: $65-73$

Fuhrman, J. A. (1990). Dissolved free amino acid cycling in an estuarine outflow plume. Mar. Ecol. Prog. Ser. 66: 197-203

Fuhrman, J. A., Azam, F. (1980). Bacterioplankton secondary production estimates for coastal waters of British Columbia, Antarctica, and California. Appl. environ. Microbiol. 39: 1085-1095
Glover, H. T (1982). Methylamine, an inhibitor of ammonium oxidation and chemoautotrophic growth in the marine nitrifying bacterium Nitrosococcus. Arch. Microbiol. 132: $37-40$

Goldman, J. C., Dennett, M. R. (1991). Ammonium regeneration and carbon utilization by marine bacteria grown on mixed substrates. Mar. Biol. 109: 369-378

Hobbie, J. E., Daley, R. J., Jasper, S. (1977). Use of nuclepore filters for counting bacteria by fluorescence microscopy. Appl. environ. Microbiol. 33: 1225-1228

Hollibaugh, J. T., Azam, F. (1983). Microbial degradation of dissolved proteins in seawater Limnol. Oceanogr. 28: $1104-1116$

Jørgensen, N. O. G. (1987). Free amino acids in lakes: concentrations and assimilation rates in relation to phytoplankton and bacterial production. Limnol. Oceanogr. 32: 97-111

Jorgensen, N.O.G. (1990). Assimilation of free monosaccharides and amino acids relative to bacterial production in eutrophic lake water. Arch. Hydrobiol. Beih. 34: 99- 110

Jørgensen, N. O. G. (1992a). Incorporation of $\left[{ }^{3} \mathrm{H}\right.$ |leucine and $\left[{ }^{3} \mathrm{H}\right]$ valine into protein of freshwater bacteria: uptake kinetics and intracellular isotope dilution. Appl. environ. Microbiol. 58: 3638-3646

Jorgensen, N. O. G. (1992b). Incorporation of $\left[{ }^{3} \mathrm{H}\right]$ leucine and $\left[{ }^{3} \mathrm{H}\right]$ valine into protein of freshwater bacteria: field applications. Appl. environ. Microbiol. 58: 3647-3653

Karl, D. M., Bailiff, M. D. (1989). The measurement and distribution of nucleic acids in aquatic environments. Limnol. Oceanogr. 34: 543-558

Keil, R. G., Kirchman, D. L. (1991a). Contribution of dissolved free amino acids and ammonium to the nitrogen requirements of heterotrophic bacterioplankton. Mar. Ecol. Prog. Ser. 73: $1-10$

Keil, R. G., Kirchman, D. L. (1991b). Dissolved combined amino acids in marine waters as determined by a vaporphase hydrolysis method. Mar. Chem. 33: 243-259

Kirchman, D. L. (1990). Limitations of bacterial growth by dissolved organic matter in the subarctic Pacific. Mar. Ecol. Prog. Ser. 62: 47-54

Kirchman, D. L., K'Nees, E., Hodson, R. E. (1985). Leucine incorporation and its potential as a measure of protein synthesis by bacteria in natural aquatic systems. Appl. environ. Microbiol. 49: 599-607

Kogura, K., Koike, I. (1987). Particle counter determinations of bacterial biomass in seawater. Appl environ. Microbiol. 53: $274-277$

Kroer, N. (1993). Bacterial growth efficiencies on natural dissolved organic matter. Limnol. Oceanogr. (in press)

Large, P. J. (1981). Microbial growth on methylated amines. In: Dalton, H. (ed.) Microbial growth on C-1 compounds. Heyden and Sons, Ltd., London, p. 55-69

Lindroth, P., Mopper, K. (1979). High performance liquid chromatographic determinations of subpicomole amounts of amino acids by precolumn fluorescence derivatization with o-phthaldialdehyde. Anal. Chem. 51: $1667-1674$

Maniatis, T., Fritsch, E. F., Sambrook, J. (1982). Molecular cloning: a laboratory manual. Cold Spring Harbor Laboratory, Cold Spring Harbor, NY

Mazzucco, C. E., Benson, D. R. (1984). $1{ }^{14}$ C|Methylammonium transport by Frankia sp. Strain Cpl1. J Bacteriol. 160: 636- 641

Middelboe, M., Nielsen, B., Søndergaard, M. (1992). Bacterial utilization of dissolved organic carbon (DOC) in coastal waters - determination of growth yield. Arch. Hydrobiol. Beih. 37: 51--61 
Neijssel, O. M., Tempest, D. W. (1975). The regulation of carbohydrate metabolism in Klebsiella aerogenes NCTC 418 organisms growing in chemostat culture. Arch. Microbiol. 106: $251-258$

Paul, J. H., DeFlaun, M. F., Jeffrey, W. H. (1988). Mechanisms of DNA utilization by estuarine microbial populations. Appl. environ. Microbiol. 54: 1682-1688

Paul, J. H., Jeffrey, W. H., Cannon, J. P. (1990). Production of dissolved DNA, RNA, and protein by microbial populations in a Florida reservoir. Appl. environ. Microbiol. 56 $2957-2962$

Paul, J. H., Jeffrey, W. H., David, A. W., Deflaun, M. F., Cazares, L. H. (1989). Turnover of extracellular DNA in eutrophic and oligotrophic freshwater environments of southwest Florida. Appl. environ. Microbiol. 55 $1823-1828$

Paul, J. H., Jeffrey, W. H., DeFlaun, M. F. (1987). Dynamics of extracellular DNA in the marine environment. Appl environ. Microbiol. 53: 170-179

Paul, J. H., Pichard, S. L. (1989). Specificity of cellular DNAbinding sites of microbial populations in a Florida reservoir. Appl. environ. Microbiol. 55: 2798-2801

Pedersen, H., Lomstein, B. Aa., Blackburn, T. H. (1993) Evidence for bacterial urea production in marine sediments. FEMS Microbiol. Ecol. 12: 51-59

Riemann, B., Bjørnsen, P. K., Newell, S., Fallon, R. (1987) Calculation of cell production of coastal marine bacteria based on measured incorporation of $\left[{ }^{3} \mathrm{H}\right]$ thymidine. Limnol. Oceanogr. 32: 471-476

Sigleo, A. C., Hare, P. E., Helz, G. R. (1983). The amino acid

This article was submitted to the editor composition of estuarine colloidal material. Estuar. coast. Shelf Sci, 17:87-96

Simon, M. (1991). Isotope dilution of intracellular amino acids as a tracer of carbon and nitrogen sources of marine planktonic bacteria. Mar. Ecol. Prog. Ser. 74: 295-301

Simon, M., Azam, F. (1989). Protein content and protein synthesis rates of planktonic marine bacteria. Mar. Ecol. Prog. Ser. 51: 201-213

Simon, M., Rosenstock, B. (1992). Carbon and nitrogen sources of planktonic bacteria in Lake Constance studied by the composition and isotope dilution of intracellular amino acids. Limnol. Oceanogr. 37: 1496-1511

Tempest, D. W., Neijssel, O. M. (1978). Eco-physiological aspects of microbial growth in aerobic nutrient-limited environments. Adv. microb. Ecol. 3: 105-153

Tupas, L., Koike, I. (1990). Amino acid and ammonium utilization by heterotrophic marine bacteria grown in enriched seawater. Limnol. Oceanogr. 35: 1145-1155

Turk, V., Rehnstam, A.-S., Lundberg, E., Hagström, А. (1992). Release of bacterial DNA by marine nanoflagellates, an intermediate step in phosphorus regeneration. Appl. environ. Microbiol. 58: 3744-3750

Yang, X.-H. (1991). Concentrations and biological uptake of three methylamines in marine, estuarine and lacustrine waters. M.S. thesis, State University of New York at Stony Brook

Yang, X.-H., Lee, C. Scranton, M. I. (1993). Determination of nanomolar concentrations of individual dissolved low molecular weight amines and organic acids in seawater. Anal. Chem. 65: 572-576

Manuscript first received: January 15, 1993

Revised version accepted: April 20, 1993 